\title{
The Stylistic Features of Chopin's Four Ballades
}

\author{
Lin $\mathrm{Li}$ \\ Academy of Music \\ Anshan Normal University \\ Anshan, China
}

\begin{abstract}
Chopin's narrative music, as an instrumental genre, shows more originality than other piano works created by him. Based on the analysis of the characteristics of the four ballades, it is clear that the themes of the four narratives are composed of singing melody, recitation, dance rhythm, and so on. "The Ballade In G Minor" expresses a kind of sadness in the tone of sighing, as if reading a sad epic; "The Ballade In F Major" uses pastoral tones and dance rhythms to express a quiet, brisk tone that seems to be reciting an elegant pastoral poem; "The Ballade In A Major" uses lyric melody and changes of high and low area to express the scene that men and women confide in each other as if reading a love poem full of tenderness; "The Ballade In F Minor" uses a euphemistic melody, accompanied by the soothing rhythm of a waltz, to express a melancholy as if singing a tearful song in a low voice. Chopin's piano narratives reflect the rapid development of the expressiveness of piano art in the early stage of romanticism. From the form of these piano works, they not only have the traditional style of perfect classic, but also have the bold innovation of originality, they not only have completed standard of form appearance, but also have the exploration and pursuit of innovation.
\end{abstract}

Keywords—romantic; ballade; stylistic

\section{INTRODUCTION}

Fryderyk Franciszek Chopin (F.F.Chopin 1810-1849), was a piano composer and pianist in 19th century Romantic Age. He completed many representative musical works in his life, in which he naturally and vividly poured the poetic melody into the various musical genres of his choice. These musical genres always show distinct musical images, unique artistic styles and rich thoughts and emotions. Chopin can be said to improve his genre of music to a new height, Ballade is one of the representative examples. The genre of ballades originated from the formative poems of the Middle Ages. It was not until 18,19 th century that some composers developed the Ballades into vocal music narratives. Chopin creatively applied the genre of narration to the creation of piano works, making it a lyrical, narrative and dramatic instrumental genre. Chopin's Ballades incorporate various elements of musical art under the social and historical trend, including the background of narrative poetry and the romantic musical temperament.

\section{BACKGROUND OF CREATION}

Chopin's "The Ballade in G Minor" was written between 1831 and 1835. He wrote the narrative in $\mathrm{g}$ minor, when Poland was in distress. Chopin had just arrived in Paris, France, and his creation had matured. The Warsaw uprising failed,
Poland became alien rule, the tragic fate of the motherland brought a heavy blow to Chopin. At this time his work style was also greatly affected. In the past, Sharon's music began to change with the tone of ornate and brisk and the creation style with Polish national characteristics. His works became more profound, and patriotism became the theme of his works. He once said, "I will make my work a war song." To some extent, the first narrative song is indeed a war song. Chopin was fond of literature when he was little, and Polish narrative poetry was often related to polish history. "The Ballade in G Minor" was Chopin's first narrative song inspired by the narrative poem "Conrad Warren Lord" by Mitzkewitz. Conrad Warren tells the story of the heroic struggle between the Lithuanian teenager Vorte and Germanic.

Chopin's "The Ballade in F Major" was written in 1839. In the fall of 1838, Chopin traveled with George Sang, the love of his life, to Majokha in the Balearic Islands in the Mediterranean. George Sang was a famous French novelist. On a trip with Chopin, she wrote: "It's a poem, a kind of serenity, a beauty of the sun. What a clear sky, what a beautiful place, we are overjoyed. " But this poetic good time did not last long, a rain caused Chopin to catch a cold, his bronchitis attack, and causing an old disease tuberculosis, Chopin began to fight with the disease. On a picturesque island, Chopin dragged the sick body and wrote "The Ballade in F Major". Up to now, we can hear the author's contradiction from the two themes of "The Ballade in F Major". The first theme seems to reflect the beautiful scenery and the happy mood, and the second theme reflects the outbreak of the composer's depressed mood and inner contradiction.

Chopin's "The Ballade in A Major" was written between 1840 and 1841. Chopin and GeorgeSand lived in a quiet environment called Noran in central France, alongside a river called Andr, where Chopin wrote this elegant and brisk work during his vacation. Chopin did not make much of statements about the narrative song before his death. There is a lot of explanation about the background of the composition of the song. Most people think that the creation of this narrative song is related to the German poet Heine's Lolele. Others believe it was based on the description of Mitzkavich's long narrative poem, the Banshee. It is not difficult to see that no matter which poem Chopin is inspired by, poetry occupies a very important position in his works and plays a decisive role in his creation.

Chopin's "The Ballade in F Minor" was written in February 1842 , which is the last work of the narrative theme. At this 
time, at the age of 32, Chopin is at the peak and mature stage of his creation. Both in terms of creative techniques and ideas, he has reached an unprecedented height. Therefore, "The Ballade in F Minor" can be said to embody the highest level of Chopin piano, which is the noblest work in Romantic music and the most difficult to understand among Chopin's four Ballades. "The Ballade in F Minor" is a tragic narrative song, which shows Chopin's nostalgia for the motherland after the defeat of the uprising.

\section{STYLE CHARACTERISTICS}

"The Ballade in G Minor" is Chopin's first narrative song, written from 1831 to 1835 . At this stage, Chopin created a new theme for his works, which is the narrative song. He began to try to innovate and integrate the sonata form, and integrate different composing principles organically and skillfully into the creation of the new form of "Piano narrative". "The Ballade in G Minor" is close to the principle of sonata in structure, including the introduction, presentation, development, reproduction and end. However, Chopin was not constrained by the traditional framework of sonata Allegro, and had carried out bold and chic innovation. First, the introduction and the end are the organic components of the whole content of the tune. Secondly, the relationship between the two themes in the presentation section is not the main and secondary opposite, but they complement each other and finish the basic music material of the music image together. Thirdly, not only the presentation part but also the connecting part, showing the effects of the bridge, and there are new music materials, which add vitality and power to the music, and drive the music forward. In addition, the reproduction section also has the main and secondary theme inversion phenomenon, as well as the new music material in the end.

Chopin's "The Ballade in G Minor" is a heroic epic. The development of music image, expression effect and meaning of music are more and more dynamic with the evolution of melody. In the final part of the narrative song, the tragic passion reached its peak. This "heroic" and "tragic" mood contained in Chopin's piano music, along with the widespread spread of the music, also inspired the Polish people of that time, as well as the peoples of Europe, who were enslaved to "oppose aggression". It was an important spiritual force in the national liberation struggle against oppression.

Chopin's "The Ballade in F Major" is the most unusual one of all his narratives. It has an extreme musical image, a bold use of the tone, a vivid musical fabric, and two contradictory musical themes cleverly combined. And the whole work was unified in contradiction. The structure and the contrast of "The Ballade in F Major" are clear. Section 1-45, a pastoral music paragraph, is the first paragraph of the music. The music is quiet and harmonious, such as the combination of melody and dance, showing a quiet, pleasant mood, both lyric and narrative. The melody of the song with ease and fluency, gives people the feeling of microwave rippling because of the three-beat dance rhythms. The first theme ends quietly and long in 45 bars. While the music was silent, the second theme appeared suddenly, agitated and full of dismay, after the extension of the mark, in section 46. The downlink is like a big wave, like a storm coming. The second theme in progress in both the sound area and intensity are gradually declining, the high part of the lower octave, symbolizing that the storm gradually subsided. The first theme reappeared in section 83 as the image of the storm subsided. The main musical image of the second narrative is the two contrasting themes. One is lyrical: quiet, clear, happy, harmonious and pastoral. One is dramatic: agitated, violent and restless. The first theme of the small board and the second theme of the fast board form a sharp priority contrast; in terms of tone, the first theme in F major and the second theme in a minor form a contrast of light and shade, in strength, the first theme of the sotto voce and the second theme of the ff formed a soft and violent contrast. Throughout the whole, the first theme is like microwave and the second is like a huge wave.

It is not difficult to see from Chopin's works that he is good at using melodies, harmonies, dynamics and rhythms to reflect the dramatic changes in themes. In "The Ballade in A Major", the structure of mixed form, the variation and development of theme, the passing sound and decorative sound are especially prominent. "The Ballade in A Major" is a work full of sunshine and vigor, bright color and enthusiasm. There are two themes in this work, and the whole song is alternated between the main theme which conveys deep emotion and the theme of two interlude characters. The first theme expresses tender feelings, mainly showing the sincere feelings of the heroine and the hero, and Chopin also melts into his emotional life in this part. The first theme begins by quoting the first four sections of the narrative song as an introduction in literary works. The second theme incorporated dance elements such as swing, bold and lively, very close to natural life. The work is rich in emotion, undulating as waves, and gradually pushing to a powerful and stirring climax.

In "The Ballade in A Major", the decorative sound in melody occupies a very important position, and it is a completely new type. They are sometimes soothing and euphemistic, like the grace and shyness of a young girl, and sometimes quick and flexible, the torrent of sound tends to rush to the end of the piano and return to its starting point. They appear in the form of a large number of rich and colorful sound groups, but never seem to interrupt the melody, and with it as a whole, showing brilliant atmosphere, flexible and changeable artistic characteristics. At the same time, it is also the characteristics of the creation of the whole song that the frequent passing notes appear in the works. In "The Ballade in A Major", Chopin used octave groups, disyllabic groups with different intervals, random transposition of various passing sounds, and the introduction of the least attuned traversals, which increase the density of the melody. And through the tone of the method of various theme, it promotes the further development of the theme.

"The Ballade in A Major" was created by Chopin in the mature period. This work fully embodies the passion and fantasy of the Romantic period. The perfect combination of skills and melodies has shaped the heroism and drama of Chopin's works.

"The Ballade in F Minor" (Op. 52) is Chopin's late work, one of the four most difficult to understand and play, which was written in 1842. Chopin's late style shows a great tendency 
to meditate and meditate. The fourth narrative song has no specific title and is the self-expression of Chopin's late mood. The fourth narrative is the largest of the four narratives and has the latest Chopin style. The singing and melody of the composition have reached a perfect combination. As one of the greatest melodic composers in the history of western music culture, Chopin's melody creation is rich in national characteristics, and its style has a natural relationship with the Polish folk music style. For example, the development of Polish folk music and the combination of singing and instrumental music are reflected in Chopin's creation of narratives. In "The Ballade in F Minor", he loved to enrich it with new variations every time he returned to the theme, and intertwined singing with instrumental music. "The Ballade in F Minor" pays attention to the synthesis of melody. For example, the melody of song sometimes has recitation, sometimes has the typical decoration, and in the second major of the theme, it makes people feel that there is the meaning of dance. There are also many melodies that combine the musical nature, the musical quality of the piano, the expressiveness of the language and the tone of the dance into a unified organism. Mattel called it a comprehensive melody, the elements of which can be found in Polish folk music, but also another source of his creation, "Italian Opera." Many researchers have noticed the relationship between Chopin's melodies and Italian opera, which is inseparable from his own familiarity with and love for opera. "It is well known that Italian opera has an influence on Chopin's creation," Mattel wrote. Many people think that the common ground between the two is reflected in the melody such as song, elegant, melodious. The structure of this narrative song is based on the combination of sonata and variation. Lyrical with melancholy and fantasy temperament, the main theme of narration strengthens the color of basic emotion through the development of variation. In the third presentation, the character changed and became full of tragic enthusiasm, while in the last statement in the reproduction ministry, the active and nervous movement brought a color of panic. The accessory uses the variation of harmony to change the color of the bright, soft lyric theme.

\section{CONCLUSION}

In the long history of the piano, romantic music is a wonderful garden, and Chopin is the most dazzling of the garden. He has formed his own unique style both in his playing style and creation. He can be said to be an artist who can represent the development direction of the major artistic styles of the nineteenth century, and he is one of the creators of the typical Romantic musical language. He is also one of the most original and creative musicians in music history. Chopin's short life left us rich treasure of piano music. His music is an immortal treasure in the history of human music, culture and art today, especially his four Ballades become classics in instrumental solo works. The crown of Chopin's Piano Poet flashes his achievements in the creation of the four piano Ballades.

\section{REFERENCES}

[1] A. Solo Pufu, Chopin's Creation [M]. People's Music Press 2006.6.
[2] Regina Smenjiang, tr. Liang Quanbing, Yao Manhua, How To Play Chopin [M]. China Literary Union Press 2003.1

[3] Pam Brown, tr. by Qi Zhongqiang and Zou Yinghui, Frederick Chopin (Series of World-famous Musicians)[M]. Foreign Affairs Press in 1998.

[4] (USA) Donald J. Glaut, Claude Pariska, The History of Western Music[M]. Beijing: Pople's Music Press, 1st edition, January 1996.

[5] Oxford Concise Music Dictionary. Pople's Music Press, Beijing, 1st Edition, 1991 (in Chinese)

[6] Zhou Wei, History of Western Piano Art[M]. Shanghai Music Press, 2003. (in Chinese) 